\title{
IN VITRO MULTIPLICATION OF Tabernaemontana fuchsiaefolia L. (Apocynaceae) $)^{1}$
}

Arildo José Braz de Oliveira², Vanda Marilza de Carvalho ${ }^{3}$, Alexandre Ferreira² ${ }^{2}$ Fernando Y. Sato ${ }^{2}$ and Maria de Fátima Pires da Silva Machado ${ }^{3,4}$

\begin{abstract}
This study describes a simple and promising for in vitro multiplication of Tabernaemontana fuchsiaefolia, a species abundantly found in southern Brazil utilized for medicinal purposes and as a source of compounds that may be used to develop new synthetic drugs. Apical and hypocotyl explants were cultured in MS medium containing different concentrations of the cytokinins benzylaminopurine (BA) and 6-furfurylaminopurine (kinetin), supplemented with phloroglucinol (1,3, 5-hydroxybenzene) to stimulate growth and shoot proliferation. Cytokinin added to the culture media positively influenced the micropropagation of $\boldsymbol{T}$. fuchsiaefolia.and kinetin induced more shoots per explant than BA cytokinin. A favorable effect of phloroglucinol on apical and lateral buds from hypocotyls was also achieved in medium containing no kinetin or in all kinetin concentrations tested. Short pulses of auxin 3-indolebutyric acid (IBA) $5.0 \mathrm{mg} / \mathrm{l}$ resulted in satisfactory rooting in apical microcuttings. The addition of phloroglucinol to MS medium induced rhizogenesis in 29\% of the nodal segments transferred to MS medium in the absence of IBA and in 50\% of the nodal segments transferred to MS medium containing $0.5 \mathrm{mg} / \mathrm{IBA}$ and in nodal segments previously submitted to short pulses of IBA.
\end{abstract}

Key words: micropropagation, Tabernaemontana fuchsiaefolia, Apocynaceae, and tissue culture.

\section{MULTIPLICAÇÃO IN VITRO DE Tabernaemontana fuchsiaefolia L. (Apocynaceae)}

Resumo - O presente estudo relata um método simples e promissor para multiplicação in vitro de Tabernaemontana fuchsiaefolia, uma espécie abundantemente encontrada no sul do Brasil, utilizada com propósitos medicinais e como fonte de compostos que podem ser usados para desenvolver novas drogas sintéticas. Para estimular o crescimento e a proliferação de caules, os explantes apicais e os hipocótilos foram cultivados em meio MS contendo diferentes concentrações das citocininas 6-benzil-amino-purina (BA) e cinetina (KIN) e suplementado com fluoroglucinol (1, 3, 5-hidroxibenzeno). A micropropagação de T. fuchsiaefolia foi positivamente influenciada por citocininas e a cinetina induziu à formação de mais caules por explantes do que a citoquinina BA. O efeito favorável de fluoroglucinol na indução de gemas apicais e laterais a partir dos hipocótilos foi verificado na ausência de cinetina ou em meio com todas as concentrações de cinetina testadas. Os caules recém-formados foram cortados dos explantes e o enraizamento satisfatório destes caules foi obtido após um tratamento com pulsos breves em 5,0 mg/l da auxina ácido 3-indolbutírico (IBA). A adição de fluoroglucinol no meio MS induziu ao enraizamento em $29 \%$ dos segmentos nodais transferidos para o meio MS na ausência de IBA, em $50 \%$ dos segmentos nodais transferidos para o meio MS contendo $0,5 \mathrm{mg} / \mathrm{l}$ de IBA e em segmentos nodais previamente submetidos aos breves pulsos de IBA.

Palavras-chave: micropropagação, Tabernaemontana fuchsiaefolia, Apocynaceae e cultura de tecidos.

\section{INTRODUCTION}

The study of different species of the genus Tabernaemontana has revealed the production of terpenoid indole alkaloids with different properties and possible applications. Information on the pharmacology of crude extract and individual alkaloids of Tabernaemontana species has been assembled by

1 Recebido para publicação em 19.7.2002.

Aceito para publicação em 9.9.2003.

2 Department of Pharmacy and Pharmacology and ${ }^{3}$ Department of Cell Biology and Genetics of State University of Maringá. 87020-900 Maringá, Paraná, Brazil. ${ }^{4}$ To whom correspondence should be addressed <mfpsmachado@uem.br>. 
Van Beek et al. (1984). These compounds generally possess characteristic biological activities and many of them are utilized for medicinal purposes and for the lead compounds they contain to develop new synthetic drugs.

Alkaloids from Tabernaemontana species have shown hypotensive and muscle relaxant activity (Perera et al., 1985; Ingkaninan et al., 1999), antimicrobial activity against Gram-positive bacteria (Van Beek et al., $1985 \mathrm{a}, \mathrm{b}$ ), and effects of sedation, decreased respiration and decreased skeletal muscle tone (Taesotikul et al., 1989), and antileishmanial and antibacterial activities (Munoz et al., 1994). The alkaloid extract of T. fuchsiaefolia shows pronounced antiophidian activity (Batina et al., 2000), and antiplasmodial activity (Federici et al., 2000).

Despite the increased interest in the use of these compounds by the pharmaceutical industry, to date, in vitro plant multiplication of this genus has not been described. Cloning individual seedlings to provide genetically uniform plant material would be useful, since many genetically uniform plants are a suitable source for industrial procedures of extraction of compounds of interest. Therefore, extraction protocols can be easily standardized using genetically uniform material. Thus, the objective of this study was to report a simple method and potential culture medium for multiplication of Tabernaemontana fuchsiaefolia, a species abundantly found in the southern Brazil.

\section{MATERIALS AND METHODS}

Donor plant. Segments of Tabernaemontana fuchsiaefolia seedlings obtained from seeds germinated in vitro were used as explants. Seeds of one T. fuchsiaefolia plant were treated with $50 \% \mathrm{HCl}(\mathrm{v} / \mathrm{v})$ for $2 \mathrm{~min}$, followed by three washes with sterile distilled water, sterilized in $95 \%$ ethanol for $1 \mathrm{~min}$, followed by two washes with sterile distilled water, and then treated with 5\% sodium hypochlorite for $10 \mathrm{~min}$, followed by three washes with sterile distilled water. The sterilized seeds were germinated on solid MS medium (Murashige $\&$ Skoog, 1962) in tissue culture flasks at $25^{\circ} \mathrm{C}$, with $16 \mathrm{~h}$ of illumination per day (light intensity, $190 \mu \mathrm{E} \mathrm{m} / \mathrm{sec}$ ). Germination occurred within 7 days and after four weeks the seeds developed into $7-8 \mathrm{~cm}$ tall seedlings.

Explant preparation and tissue culture media. Transverse segments approximately $0.8-1.0 \mathrm{~cm}$ in length containing the cotyledons or axillaries buds obtained from hypocotyls were inoculated into MS medium supplemented with $2.0 \mathrm{mg} / \mathrm{l}$ of benzylaminopurine (BA; $1 \mathrm{mg} / \mathrm{l}=4.40 \mu \mathrm{M}$ ) or 6-furfurylaminopurine (kinetin; $1 \mathrm{mg} / \mathrm{l}=4.60 \mu \mathrm{M})$ to evaluate the effect of two different cytokinins on micropropragation of $\mathrm{T}$. fuchsiaefolia. This experiment was replicated three times each for the cytokinins BA and kinetin, and the three flasks containing 7-8 explants each were incubated at $25^{\circ} \mathrm{C}$ with $16 \mathrm{~h}$ illumination per day.

In the experiment conducted to test the different concentrations of kinetin, transverse segments approximately $1.0-1.5 \mathrm{~cm}$ in length were cut from the hypocotyls, and the explants were then placed in flask containing solid MS medium, $0.8 \%$ agar, $30 \mathrm{~g} / \mathrm{l}$ sucrose, $\mathrm{pH} 5.8$, supplemented with $0.0,2.0,4.0$ and $6.0 \mathrm{mg} / \mathrm{l}$ of kinetin. An additional supplement, i.e., the phenolic compound phloroglucinol (1,3, 5-hydroxybenzene), was also tested to stimulate growth and shoot proliferation. The two experiments MS medium and MS medium containing $100 \mathrm{mg} / \mathrm{l}$ phoroglucinol and different kinetin concentrations were replicated three times at each kinetin concentration. After inoculation, the flasks containing 7-8 explants (apical and shoot explants) were incubated at $25^{\circ} \mathrm{C}$, with $16 \mathrm{~h}$ of illumination per day.

To initiate rooting, 2 to $3 \mathrm{~cm}$ long microcuttings were transferred to MS medium, MS medium supplemented with $0.5 \mathrm{mg} / \mathrm{l}$ of 3-indolebutyric acid (IBA; $1 \mathrm{mg} / \mathrm{l}=$ $4.90 \mu \mathrm{M})$, and microcuttings were inoculated into MS medium after washing (1-2 minutes) with a solution of $5.0 \mathrm{mg} / \mathrm{l} \mathrm{IBA}$. The same procedure was applied to microcuttings obtained in MS medium supplemented with phloroglucinol $(100 \mathrm{mg} / \mathrm{l})$. Rooted plantlets were washed in tap-water and transferred to plastic chambers containing a sterilized mixture of sand and soil (1:1), and covered with a plastic cap that was gradually opened during the acclimation period of 15 days. Acclimated plants were transferred to the greenhouse and then to outdoor conditions.

\section{RESULTS AND DISCUSSION}

Cytokinin in the culture media positively influenced the micropropagation of T. fuchsiaefolia. Adventitious buds were stimulated in $100 \%$ of the segments containing the cotyledons and in $80 \%$ of the segments containing axillary buds cultured in MS supplemented with $2.0 \mathrm{mg} / \mathrm{l}$ kinetin. In MS medium supplemented with $2.0 \mathrm{mg} / \mathrm{l}$ of BA $83 \%$ and $5 \%$ of the segments containing 
cotyledons and axillary buds, respectively, produced adventitious buds. These experiment showed that kinetin induced more shoots per explant than the BA cytokinin. The high number of adventitious buds produced in the presence of cytokinins is consistent with the general knowledge that cytokinins overcome apical dominance, release lateral buds from dormancy and promote shoot formation (George, 1993).

Based on the above results, the different concentrations of kinetin were evaluated in apical and tall segments of $T$. fuchsiaefolia. The apical and tall segments were separately analyzed in vitro. The production of internodal segments from apical explants, as well as the number of buds induced from hypocotyls were recorded for each experiment after 48 days of culture. Table 1 shows the number of internodal segments produced from the growth of apical explants and tall segments. The addition of phloroglucinol to MS medium at the different kinetin concentrations increased hypocotyl growth and induced a higher number of internodal segments containing two leaves per node (Figure 1). However, the different kinetin concentrations did not seem to be essential for internodal segment production.

The favorable effect of phloroglucinol on apical and lateral buds from hypocotyls was also achieved in medium containing no kinetin or all kinetin concentrations tested (Table 1). Hypocotyls cultured in MS medium plus phloroglucinol produced new buds containing two nodes each from the apical region of hypocotyls. Positive effects of phloglucinol on the stimulation of growth and shoot proliferation has been reported for some cultivars and woody species (Jones, 1976).

Table 1 - Number of internodal segments (IS) produced by apical and tall explants of Tabernaemontana fuchsiafolia growing in MS medium (MS) and in MS medium supplemented with phloroglucinol (MS + Pho) and different concentrations of kinetin.

Quadro 1 - Número de segmentos internodais (IS) produzidos pelos explantes apicais e pelos segmentos de talos de Tabernaemontana fuchsiafolia crescendo em meio MS (MS) e em meio MS suplementado com fluoroglucinol (MS + Pho) e diferentes concentrações de cinetina

\begin{tabular}{|c|c|c|c|c|}
\hline \multirow{2}{*}{$\begin{array}{c}\text { Kinetin } \\
(\mathrm{mg} / \mathrm{l})\end{array}$} & \multicolumn{2}{|c|}{ IS / apical explants } & \multicolumn{2}{c|}{ IS/ tall explants } \\
\cline { 2 - 5 } & MS & MS + Pho & MS & MS + Pho \\
\hline 0.0 & $0 / 3$ & $6 / 3$ & $6 / 8$ & $8 / 8$ \\
\hline 2.0 & $3 / 3$ & $4 / 3$ & $1 / 4$ & $6 / 4$ \\
\hline 4.0 & $2 / 4$ & $4 / 2$ & $1 / 4$ & $6 / 4$ \\
\hline 6.0 & $4 / 3$ & $6 / 3$ & $5 / 8$ & $2 / 4$ \\
\hline
\end{tabular}

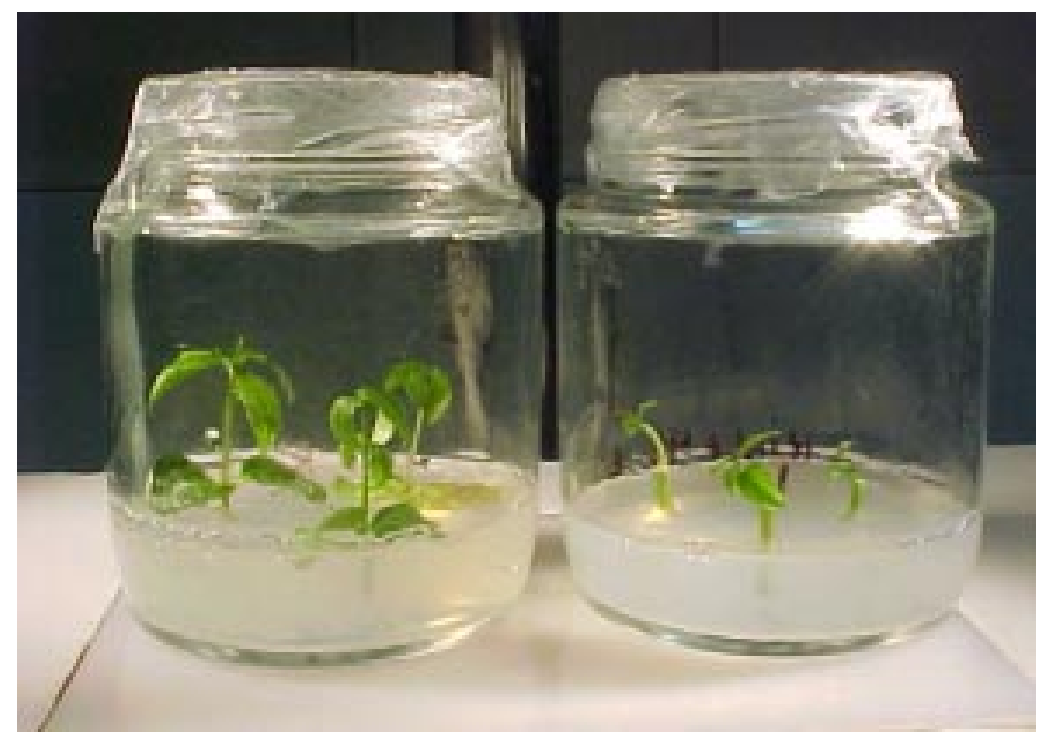

Figure 1 - Effect of kinetin (2.0 mg/l) on apical explants (A) and tall segment explants (B) showing the lateral buds induced at the top of hypocotyls (arrows).

Figura 1 - Efeito de cinetina (2.0 mg/I) nos explantes apicais (A) e nos segmentos de tal os (B) mostrando as gemas laterais induzidas no ápice dos hipocótilos (setas). 
Root formation occurred only in apical explants cultured in the absence of kinetin or in MS medium supplemented with phloroglucinol and $2.0 \mathrm{mg} / \mathrm{l} \mathrm{kinetin.}$ Cytokinins generally inhibit rooting (Hussey, 1986) and rooting of the new microcuttings ( 2 to $3 \mathrm{~cm}$ long) excised from micropropagated plantlets produced on MS without growth regulators or on MS supplemented with kinetin and phloroglucinol occurred 4 weeks after transfer of the microcuttings to MS medium in the absence of kinetin. Formation of 1.0-2.2 cm long roots occurred in $50 \%$ of the apical microcuttings transferred to MS medium and to MS medium containing $0.5 \mathrm{mg} / \mathrm{l} \mathrm{IBA}$. The addition of $0.5 \mathrm{mg} / 1 \mathrm{IBA}$ to $\mathrm{MS}$ medium did not enhance root induction, but rooting was $100 \%$ when short IBA pulses of $5.0 \mathrm{mg} / \mathrm{l}$ were applied for a period of 1-2 min before microcutting transfer to MS medium. Short auxin pulses have resulted in satisfactory rooting in other wood plant species (Roussos et al., 1999).

IBA, $0.5 \mathrm{mg} / \mathrm{l}$ in MS medium, or short IBA pulses of $5.0 \mathrm{mg} / \mathrm{l}$ were not effective for root induction in nodal segments excised from micropropagated plantlets. Root induction in nodal microcuttings occurred only in MS medium containing phloroglucinol. The addition of phloroglucinol to MS medium induced rhizogenesis in $29 \%$ of the nodal segments transferred to MS medium in the absence of IBA and in $50 \%$ of the nodal segments transferred to MS medium containing $0.5 \mathrm{mg} / \mathrm{l} \mathrm{IBA}$ and in nodal segments previously submitted to the short IBA pulses. The effect of phloroglucinol on rhizogenesis seems to be species specific since this positive effect has been reported for fruit trees (James \& Thurbon, 1981) while root inhibition has been reported by Snir \& Erez (1980) and Zimmerman \& Forolham (1985) for different plant species.

Since a favorable effect of phloroglucinol on bud and root induction was observed in T. fuchsiafolia, the addition of phloroglucinol to MS medium within or without kinetin or IBA can be considered to be an effective method for in vitro multiplication of this plant species: one seedling (7-8 cm in length) produces one apical and 3-4 hypocotyl segments used as explants, which can be the source of 7-8 new genetically uniform seedlings.

\section{BIBLIOGRAFIC REFERENCES}

BATINA, M. D. et al. Inhibition of the lethal and myotoxic activities of Crotalus durissus terrificus venom by Tabernaemontana catharinensis: identification of one of the active components. Planta Medica, v. 66, p. 424-428, 2000.

R. Árvore, Viçosa-MG, v.27, n.4, p.421-425, 2003
FEDERICI, E. et al. Antiplasmodial activity of the alkaloids of Peschiera fuchsiafolia. Planta Medica, v. 66, p. 93-95, 2000.

GEORGE, G. F. Plant propagation by tissue culture. Part 1, The technology. Edington, Exegetics. 1993.

HUSSEY, G. Vegetative propagation of plants by tissue culture. In: YEOMAN, M. M. (Ed.) Plant cell culture technology. Oxford: Blackwell Scientific Publications, 1986. p. 29-66.

INGKANINAN, K. et al. Isolation of opioid-active compounds from Tabernaemontana pachysiphon leaves. Journal Pharm. Pharmacology, v. 51, p. 1441-1446, 1999.

JAMES, D. J.; THURBON, I. J. Shoot and root initiation in vitro in the apple rootstock M.9 and the promotive effects of phloroglucinol. Journal Horticulture Science, v. 56, p. 1520, 1981 .

JONES, O. P. Effect of phloridzin and phloroglucinol on apple shoots. Nature, v. 262, p. 392-393, 1976.

MUNOZ, V. et al. Isolation of bis-indole alkaloids with antileishmanial and antibacterial activities from Peschiera van heurkii (syn. Tabernaemontana van heurkii). Planta Medica, v. 60, p. 455-459, 1994.

MURASHIGE, T.; SKOOG, F. A revised medium for rapid growth and bioassays with tobacco cultures. Physiology Plantarum, v. 15, p. 473-497, 1962.

PERERA, P. et al. Muscle relaxant activity and hypotensive activity of some Tabernaemontana alkaloids. Journal Ethnopharmacology, v. 13, p. 165-173, 1985.

ROUSSOS, P. A. et al. Rapid multiplication of Jojoba seedlings by in vitro culture. Plant Cell Tissue and Organ Cult., v. 57, p. 133-137, 1999.

SNIR, I.; EREZ, A. In vitro propagation of Malling Merton apple rootstocks. HortScience, v. 15, p. 597-598, 1980.

TAESOTIKUL, T. et al. Hippocratic screening of ethanolic extracts from two Taberanaemontana species. Journal Ethnopharmacology, v. 27, p. 99-106, 1989.

Van BECK, T. A.; SMIDT, C.; VERPOOTE, R. Phytochemical investigation of Tabernaemontana crassa. Journal Ethnopharmacology, v. 14, p. 315-318, 1985 b.

Van BECK, T. A. et al. Antimicrobially active alkaloids from Tabernaemontana chippii. Journal Natural Production, v. 48, p. 400-423, 1985a. 
Van BECK, T. A. et al. Tabernaemontana L. (Apocynaceae): a review of its taxonomy, phytochemistry, ethnobotany and pharmacology. Journal

Ethnopharmacology, v. 10, p. 1-156, 1984.
ZIMMERMAN, R. H.; FORDHAM, I. Simplified method for rooting apple cultivars in vitro. Journal American Society of Horticultural Science, v. 110, p. 34-38, 1985. 